\title{
New Geological Evidence of the 1755 Lisbon Tsunami from the Rock of Gibraltar (Southern Iberian Peninsula)
}

\author{
Francisco Ruiz ${ }^{1,2} * \mathbb{D}$, Manuel Pozo ${ }^{3} \mathbb{D}$, María Luz González-Regalado ${ }^{1}$, Joaquín Rodríguez Vidal ${ }^{1,2} \mathbb{D}$, \\ Luis Miguel Cáceres ${ }^{1}$, Manuel Abad 4 (D), Tatiana Izquierdo 4 ${ }^{(D)}$, María Isabel Prudencio ${ }^{5}$, María Isabel Dias 5 , \\ Rosa Marques $^{5}$ D, Juan M. Muñoz-Pichardo ${ }^{6}{ }^{\mathbb{D}}$, Josep Tosquella ${ }^{1}$, Paula Gómez ${ }^{1}$, Antonio Toscano ${ }^{1}$, \\ Verónica Romero ${ }^{1}$ and Marta Arroyo ${ }^{1}$
}

Citation: Ruiz, F.; Pozo, M.; González-Regalado, M.L.; Rodríguez Vidal , J.; Cáceres, L.M.; Abad, M.; Izquierdo, T.;

Prudencio, M.I.; Dias, M.I.;

Marques, R.; et al. New Geological

Evidence of the 1755 Lisbon Tsunami from the Rock of Gibraltar (Southern Iberian Peninsula). Minerals 2021, 11, 1397. https://doi.org/10.3390/ $\min 11121397$

Academic Editor: Luca Aldega

Received: 19 October 2021

Accepted: 30 November 2021

Published: 10 December 2021

Publisher's Note: MDPI stays neutral with regard to jurisdictional claims in published maps and institutional affiliations.

Copyright: (c) 2021 by the authors. Licensee MDPI, Basel, Switzerland. This article is an open access article distributed under the terms and conditions of the Creative Commons Attribution (CC BY) license (https:// creativecommons.org/licenses/by/ $4.0 /)$.
1 Departamento de Ciencias de la Tierra, Universidad de Huelva, Avda. Tres de Marzo, s/n, 21071 Huelva, Spain; montero@uhu.es (M.L.G.-R.); jrvidal@uhu.es (J.R.V.); mcaceres@dgeo.uhu.es (L.M.C.); josep@uhu.es (J.T.); paula.gomezgutierrez@hotmail.com (P.G.); antonio.toscano@dgyp.uhu.es (A.T.); vero.ra93@gmail.com (V.R.); mararser@gmail.com (M.A.)

2 Centro de Investigación en Patrimonio Histórico, Cultural y Natural (CIPHCN), Universidad de Huelva, Avda. Tres de Marzo, s/n, 21071 Huelva, Spain

3 Departamento de Geología y Geoquímica, Universidad Autónoma de Madrid, Avda. Francisco Tomas y Valiente 7, 28049 Madrid, Spain; manuel.pozo@uam.es

4 Departamento de Biología y Geología, Física y Química Inorgánica, ESCET, Universidad Rey Juan Carlos, 28933 Móstoles, Spain; manuel.abad@urjc.es (M.A.); tatiana.izquierdo@urjc.es (T.I.)

5 Centro de Ciências e Tecnologias Nucleares (CCTN), Universidade de Lisboa, 1649-004 Lisboa, Portugal; iprudenc@ctn.tecnico.ulisboa.pt (M.I.P.); isadias@ctn.tecnico.ulisboa.pt (M.I.D.); rmarques@ctn.tecnico.ulisboa.pt (R.M.)

6 Departamento de Estadística e Investigación Operativa, Universidad de Sevilla, C/Tarfia, s/n, 41012 Sevilla, Spain; juanm@us.es

* Correspondence: ruizmu@uhu.es; Tel.: +34-959-219-850

Abstract: This paper presents the easternmost mineralogical and geochemical evidence of the 1755 Lisbon tsunami found in the Western Mediterranean. This multidisciplinary analysis of a sediment core obtained in Gibraltar (southern Iberian Peninsula) has allowed us to differentiate a tsunamiite from an old lagoon (The Inundation). This tsunamigenic layer has increased levels of calcite and aragonite and higher concentrations of $\mathrm{Ba}$ and ferromagnesian elements in comparison with the underlying lagoonal sediments of this core. This layer is also differentiated by its paleontological record, with the introduction of marine species within this lagoon. The uppermost part of the core includes a transition from swampy/marsh paleoenvironments to terrestrial scenarios, with a final anthropogenic filling occurring during the last century.

Keywords: 1755 Lisbon tsunami; tsunamiite; geological features; Gibraltar; southern Iberian Peninsula

\section{Introduction}

Research on tsunami deposits has grown exponentially since the 2004 Indian Ocean Tsunami [1,2], the 2010 Maule Tsunami [3,4], and the 2011 Tohoku-oki Tsunami [5,6], with numerous papers dedicated to the associated tsunamiites. Special attention has been paid to their textural and stratigraphic features $[7,8]$, macrofauna and microfauna $\mathrm{m}$, geochemistry [11,12], and the associated coastal changes [13,14]. In most of these investigations, mineralogy has not been analyzed nor has it played a secondary role in the detection of these tsunamigenic layers. Furthermore, few papers have considered both the mineralogical and geochemical features of tsunamiites $[15,16]$. The use of a multivariate analysis to differentiate tsunamigenic layers and infer the provenance of the materials that they contain has been even rarer [17].

On November 1, 1755, a tremendous earthquake $M_{w}(\sim 8.5 \pm 0.3)$ [18] devastated the southwestern regions of Europe. This destructive cataclysm was felt as far away as Germany and Finland [16]. This great earthquake and the associated tsunami caused 
tens of thousands of deaths in Portugal, Spain, and NW Morocco [19-21]. There were historical reports of tsunami waves as high as $10 \mathrm{~m}$ along the Atlantic coast of the Iberian Peninsula [22]. The geological effects of this tsunami extended mainly along the Atlantic coasts of Portugal, Spain, and Morocco (Figure 1A), although this transoceanic tsunami even reached the Lesser Antilles Arc [23]. This record was detected in old lagoons, estuaries, capes, and bays (see case studies in [15,24-26]). Despite this huge collection of research, there are hardly any data on the mineralogical changes associated with this event [27] and, consequently, new investigations are necessary to detect its mineralogical signal.

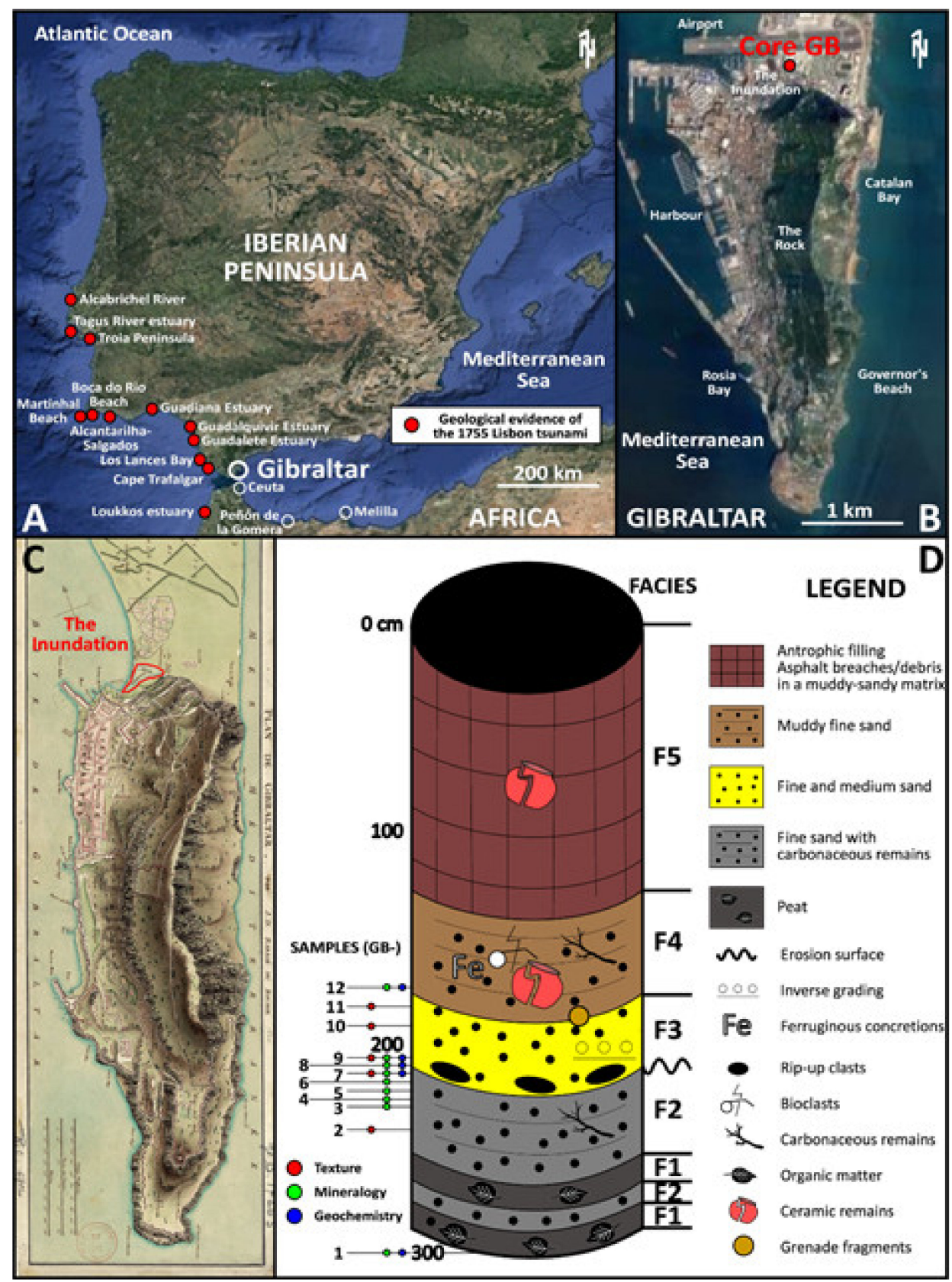

Figure 1. (A) Geological evidence of the 1755 Lisbon tsunami along the Atlantic coasts of Portugal, Spain, and Morocco; (B) the Rock of Gibraltar: location of core GB; (C) Gibraltar: historical map of 1799; (D) log of core GB, including sampling and facies analysis.

In this paper, we intend to detect the easternmost geological evidence of the 1755 Lisbon Tsunami near the Atlantic-Mediterranean boundary. For this purpose, we analyzed 
the facies distribution, the mineralogical and geochemical features, and the radiometric age of a core extracted in Gibraltar (S Iberian Peninsula) in order to infer the paleoenvironmental evolution of this area during the late Holocene in direct correlation with the paleontological record. In addition, we applied multivariate statistical methods to both mineralogical and geochemical data with two objectives: (i) to detect tsunamigenic layers and (ii) to deduce the origin of the geological materials contained within them. In summary, this paper tries to show an example of the integration of the data provided by different geological disciplines to distinguish tsunamiites in coastal environments.

\section{Study Area}

The Rock of Gibraltar is located in the southernmost area of the Iberian Peninsula, close to the Atlantic-Mediterranean limit (Figure 1B). Consequently, it is an excellent place to obtain a geological record of tsunamis from these two facades. The Rock $m$ is mainly formed of Jurassic dolomites with intense karstification and Pleistocene formations. It is linked with the mainland through an isthmus, which was occupied by an old lagoon (Figure, 1C: The Inundation) until the end of the 19th century.

The historical cartography, available for consultation at the Gibraltar Museum, shows that this lagoon was progressively isolated from the open sea by a coastal barrier, which had only one natural exit towards its southern end around 1755. An available map from 1799 (Figure 1C) does not show a washover fan inside the lagoon and, consequently, a possible tsunamiite derived from the 1755 Lisbon tsunami could have been deposited at the bottom of this old lagoon. This previous historical research justified our choice of the coring site (Figure 1B: core Gibraltar -GB-).

\section{Materials and Methods}

\subsection{Sampling}

Core GB $\left(36^{\circ} 8^{\prime} 53^{\prime \prime} \mathrm{N} ; 5^{\circ} 20^{\prime} 49^{\prime \prime} \mathrm{W} ; 3 \mathrm{~m}\right.$ depth) was extracted from the innermost part of the old Inundation lagoon (Figure 1B). It was performed by the geotechnical company Sergeyco Andalucía S.L. for the expansion of the airport, using usual rotary drilling techniques with a continuous recovery of sediment. Twelve samples were selected from the different sedimentary facies of core GB (Figure 1D). Additional subsamples were extracted for textural, paleontological, mineralogical, and geochemical analyses.

\subsection{Facies Analysis}

First, a visual analysis of the facies was carried out on core GB, taking into account the lithology, color, sedimentary structures, boundaries between the different sedimentary units, faunal content, and other differentiating elements (Figure 1D). Five subsamples chosen for a grain size analysis were dried at room temperature and sieved through a $2 \mathrm{~mm}$ sieve to separate the gravel fraction. A Malvern Mastersizer 2000 (Malvern Instruments Ltd. Malvern, UK) was used to determine the particle size of sediments under $2 \mathrm{~mm}$. In addition, a sample of each facies $(20 \mathrm{~g})$ was studied in a macropaleontological analysis, with the determination of the total population carried out according to the World Register of Marine Species (WoRMS).

\subsection{Mineralogy}

Nine samples (10 g; $2 \mathrm{~cm}$ thickness) were selected for a mineralogical analysis, including a sample of each facies and a set of five samples collected at depths between $235 \mathrm{~cm}$ and $210 \mathrm{~cm}$. The last samples were obtained from the different subfacies of the supposedly tsunamigenic facies and the underlying sediments. A mineralogical analysis of these samples (\% weight) was carried out by means of X-ray diffraction (XRD, Universidad Autónoma de Madrid, Madrid, Spain) using a SIEMENS D-5000 with a scanning speed of $1^{\circ} 2 \theta / \mathrm{min}$ and $\mathrm{Cu}-\mathrm{k} \alpha$ radiation $(40 \mathrm{kV}, 20 \mathrm{~mA})$. XRD studies were carried out on randomly oriented bulk samples. Powdered $(<63 \mu \mathrm{m})$ whole-rock samples were scanned from $2^{\circ}$ to $65^{\circ} 2 \theta$. A semi-quantitative estimation of the mineral content was carried out using 
intensity factors [28]. This standard procedure has been applied in other mineralogical studies of coastal sediments [29,30].

\subsection{Geochemistry}

A geochemical analysis of five of the samples was carried out at the Spanish Geological and Mining Institute (Madrid). The concentrations of eighteen elements were analyzed using ICP-MS. A sample was collected from three sedimentary facies and two samples were obtained in the supposedly tsunamigenic facies. The concentrations of sixteen elements were analyzed using ICP-MS (Agilent ICP-MS 7700 series) with different analytical errors (see Table 1). The samples were analyzed by acid digestion $\left(\mathrm{HF}, \mathrm{HNO}_{3}\right.$, and $\left.\mathrm{HCl}\right)$ after the standard procedure. The quality was contrasted by the intercomparison tests of the International Association of Geoanalysts (IAG).

Table 1. Core GB: grain-size parameters.

\begin{tabular}{ccccc}
\hline Facies & Sediment & Mean (phi) & Sorting & Skewness \\
\hline F3b (top) & Medium sand & 1.84 & 0.98 (poorly sorted) & Symmetrical \\
\hline F3b (base) & Medium sand & 1.9 & 1.05 (poorly sorted) & Fine skewed \\
\hline F3a & Fine sand & 2.56 & 1.11 (poorly sorted) & Fine skewed \\
\hline F2 (top) & Fine sand & 2.53 & 1.4 (poorly sorted) & Symmetrical \\
\hline F2 (base) & Fine sand & 2.49 & 1.51 (poorly sorted) & Coarse skewed \\
\hline
\end{tabular}

\subsection{Dating}

At the Beta Analytic Laboratory (Miami, FL, USA), two dates were obtained from two samples (bulk organic matter) extracted at depths of $3.00 \mathrm{~m}$ and $2.15 \mathrm{~m}$ for radiocarbon dating (AMS). These dates were calibrated with the program Calib 8.2 and the IntCal20 Northern Hemisphere Radiocarbon Age Calibration Curve [31], and the final results were expressed as the highest probable age of the 2 sigma calibrated range. In addition, some grenade fragments were extracted at a $\sim 1.8 \mathrm{~m}$ depth.

\section{Results}

\subsection{Facies}

Based on their textural, stratigraphical, and macrofaunal characteristics, the sediments of core GB can be divided into five facies. Facies 1 (Figure 1D: F1) consists of dark peats with a high organic matter content, numerous plant remains, and scarce sandy silts. Facies 2 (Figure 1D: F2) is interbedded with F1 near the base of the core. This facies is mainly composed of poorly sorted fine sands (Figure 2: 46-52 wt \%) with minor percentages of muds (silt + clays: $22-24 \mathrm{wt} \%$ ). In this facies, the sorting decreases (1.51 to 1.4) upwards (Table 1). The brackish gastropod Hydrobia acuta is very abundant in this facies.

Facies 3 (Figure 1D: F3; 2.15-8 m depth) includes two subfacies (Figure 1D: F3a and F3b). The basal F3a presents the following characteristics: (i) its lower contact is erosional with a warped surface; (ii) rip-up clasts derived from F1 and F2 are frequently seen in the lower 3-5 cm; (iii) it is composed of poorly sorted fine sands with important percentages of bioclastic medium sands (bioclasts $>20 \mathrm{wt} \%$ ); and (iv) these bioclastic sediments contain an abundant assemblage of marine (M) and brackish (B) gastropods, such as Calliostoma laugieri (M), Jujubinus striatus (M), Tricolia tenuis (M), and Peringia ulvae (B). The transition to F3b (bioclastic medium sands) is marked by an increase in grain size caused by the presence of numerous shells of the gastropods Peringia ulvae and Hydrobia acuta and scarce specimens of marine species. 


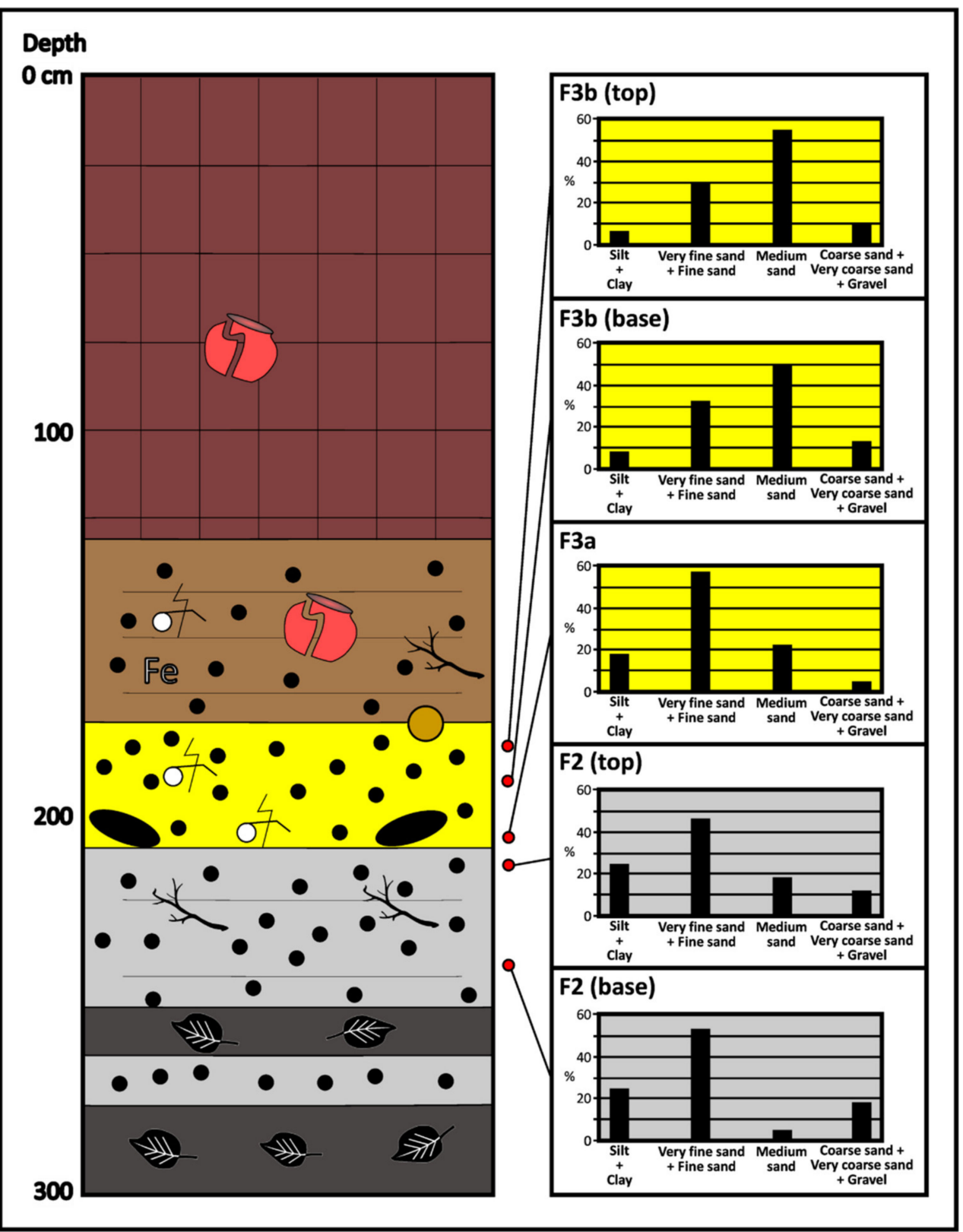

Figure 2. Textural analysis of core GB. For legend, see Figure 1. Depth in cm.

\subsection{Mineralogy}

The mineralogical composition of the core GB is clearly dominated by quartz (Figure 3), with a peak in some samples of F1 and F2 (>97.4 wt \%) and the lowest percentages seen near the base of F3 (89.9-90.1 wt \%). Calcite only exceeds 4 wt \% in F4 (7.1 wt \%) and F3 (F3a: $5.5 \mathrm{wt} \%$; F3b: $4.3 \mathrm{wt} \%$ ), while gypsum decreases upwards in F2 (4.4 wt \% to $0.12 \mathrm{wt} \%)$ and is poorly represented both in F1 (1.04 wt \%) and F3a (0.79 wt \%). Plagioclase only exceeds $1 \mathrm{wt} \%$ in F3a, while mica and aragonite have their maximums in this subfacies ( $2.7 \mathrm{wt} \%$ and $1.17 \mathrm{wt} \%$, respectively). In addition, $\mathrm{k}$-feldspar reaches its maximum in F3b $(2.81 \mathrm{wt} \%)$. 

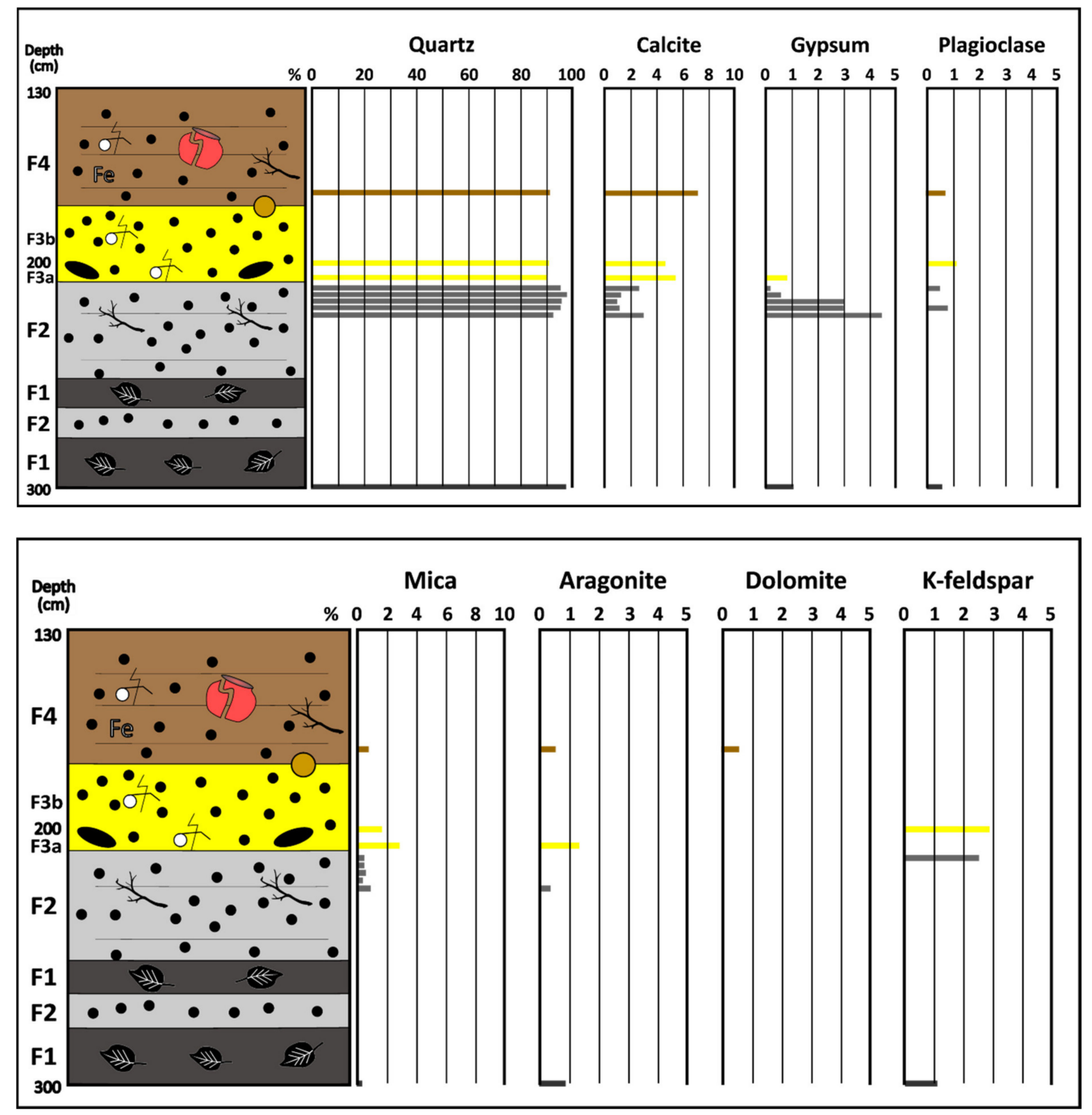

Figure 3. Mineralogical analysis of core GB.

Traces of mica, aragonite, K-feldspar, and dolomite were also detected (Figure 3: $<3 \mathrm{wt} \%$ in all samples). The first three reach their maximum percentages near the base of F3 (2.7 wt \%, $1.17 \mathrm{wt} \%$ and $2.49 \mathrm{wt} \%$, respectively), while the latter was only detected in F4 (0.53 wt \%).

The linear correlation analysis (Figure 4A) only provided a positive significant coefficient between dolomite and calcite $(r=0.68 ; p<0.05)$. The cluster analysis detected two mineralogical groups of samples (Figure 4C). Group M1 included the lowest of the five samples studied (F1 and F2), characterized by the highest mean percentages of quartz (95.47\%) and gypsum (2.38\%). The uppermost four samples (group M) presented slightly lower mean values of quartz (91.19\%) and higher calcite contents (4.83\%). This group was formed of the upper sample of F2 (GB-7), a sample of each subfacies of F3, and a sample of F4. 


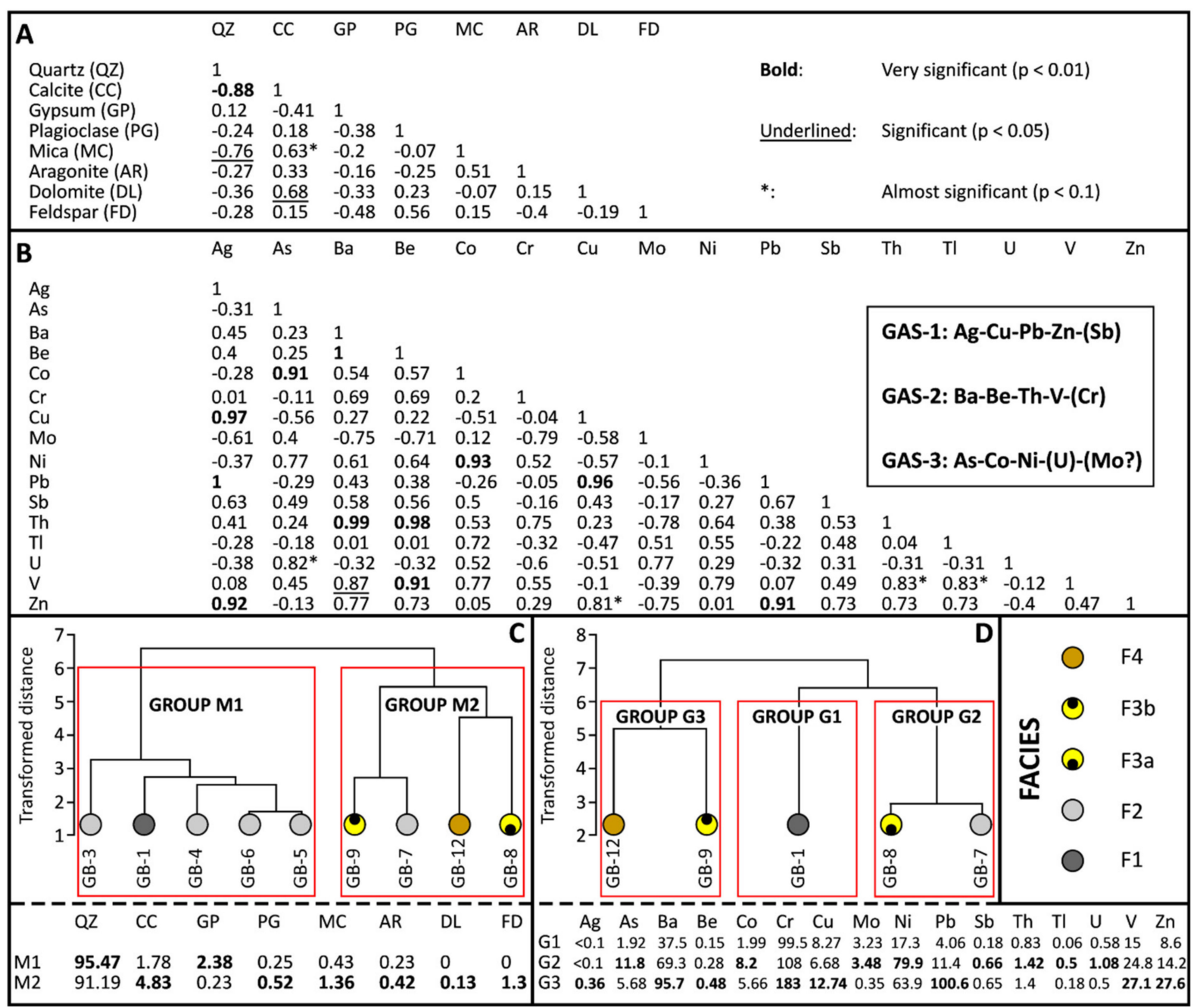

Figure 4. Statistical analysis. (A) Mineralogy: linear correlation; (B) geochemistry: linear correlation; (C) mineralogy: cluster analysis; (D) geochemistry: cluster analysis.

\subsection{Geochemistry}

The previously differentiated facies had a distinctive geochemical signature. F1 was characterized by the lowest values of almost all elements (Table 2). These values increased in $\mathrm{F} 2$, especially $\mathrm{Tl}(0.55 \mu \mathrm{g} / \mathrm{kg})$ and $\mathrm{U}(1.16 \mu \mathrm{g} / \mathrm{kg})$. This increasing trend continued in F3a, which presented the highest values of As $(12.3 \mu \mathrm{g} / \mathrm{kg}), \mathrm{Co}(9.62 \mu \mathrm{g} / \mathrm{kg}), \mathrm{Mo}(3.59 \mu \mathrm{g} / \mathrm{kg})$, and $\mathrm{V}(31.5 \mu \mathrm{g} / \mathrm{kg})$. The transition to F3b was characterized by an increase in nine of the elements, especially in $\mathrm{Cr}(108$ to $242 \mu \mathrm{g} / \mathrm{kg})$, while five of the elements decreased (As, Co, Mo, Sb, U). F4 showed the highest values of As $(0.6 \mu \mathrm{g} / \mathrm{kg}), \mathrm{Cu}(18.5 \mu \mathrm{g} / \mathrm{kg}), \mathrm{Pb}$ $(181 \mu \mathrm{g} / \mathrm{kg}), \mathrm{Sb}(0.88 \mu \mathrm{g} / \mathrm{kg})$, and $\mathrm{Zn}(34.1 \mu \mathrm{g} / \mathrm{kg})$.

In total, three geochemical associations were defined from the analysis of Pearson's linear correlation coefficients (Figure 4B: GAS-). The highest values of GAS-1 (Ag- $\mathrm{Cu}-\mathrm{Pb}-$ $\mathrm{Zn}$ ) were associated with F4, while most of the elements of GAS-2 (Ba-Be-Th-V) reached their maximum values in F3b. Finally, GAS-3 (As-Co-Ni) was found to be more abundant in F3a.

The geochemical analysis differentiated three groups of samples. Group G1 (sample GB-1) was defined by the lowest values of almost all elements. Group G2 was composed of the uppermost sample of $\mathrm{F} 2$ and the basal sample of F3a, which presented high values of GIS-3. Group G3 included two samples of F3b and F4, with the highest content of GIS-1 and GIS-2. 
Table 2. Geochemistry of selected samples. Bold: highest value; underlined: lowest value.

\begin{tabular}{|c|c|c|c|c|c|c|c|}
\hline \multirow{2}{*}{ SAMPLE } & \multirow{2}{*}{ DEPTH (cm) } & \multirow{2}{*}{ FACIES } & ELEMENT $(\mu \mathrm{g} / \mathrm{kg})$ & Ag & As & Вa & $\mathrm{Be}$ \\
\hline & & & Analytical Error $(\mu \mathrm{g} / \mathrm{kg})$ & 0.1 & 0.1 & 0.1 & 0.1 \\
\hline GB-12 & 170 & & F4 & 0.6 & 4.9 & 90.4 & 0.44 \\
\hline GB-9 & 210 & & F3 & 0.12 & 6.46 & 101 & 0.52 \\
\hline GB-8 & 215 & & F3 & $<0.1$ & 12.3 & 81.9 & 0.42 \\
\hline GB-7 & 220 & & F2 & $<0.1$ & 11.4 & 56.7 & 0.25 \\
\hline GB-1 & 300 & & F1 & $<0.1$ & $\underline{1.92}$ & 37.5 & 0.15 \\
\hline \multirow{2}{*}{ SAMPLE } & \multirow{2}{*}{ DEPTH (cm) } & \multirow{2}{*}{ FACIES } & ELEMENT ( $\mu \mathrm{g} / \mathrm{kg})$ & Co & $\mathrm{Cr}$ & $\mathrm{Cu}$ & Mo \\
\hline & & & Analytical Error $(\mu \mathrm{g} / \mathrm{kg})$ & 0.2 & 0.1 & 0.2 & 0.1 \\
\hline GB-12 & 170 & & F4 & 4.4 & 124 & 18.5 & 0.65 \\
\hline GB-9 & 210 & & F3 & 6.93 & 242 & 6.99 & $\leq 0.1$ \\
\hline GB-8 & 215 & & F3 & 9.62 & 108 & 4.5 & 3.59 \\
\hline GB-7 & 220 & & F2 & 6.78 & 108 & 4.86 & 3.38 \\
\hline GB-1 & 300 & & F1 & $\underline{1.99}$ & 99.5 & 8.27 & 3.23 \\
\hline \multirow{2}{*}{ SAMPLE } & \multirow{2}{*}{ DEPTH (cm) } & \multirow{2}{*}{ FACIES } & ELEMENT ( $\mu \mathrm{g} / \mathrm{kg})$ & $\mathrm{Ni}$ & $\mathrm{Pb}$ & $\mathrm{Sb}$ & Th \\
\hline & & & Analytical Error $(\mu \mathrm{g} / \mathrm{kg})$ & 0.1 & 2 & 0.1 & 0.05 \\
\hline GB-12 & 170 & & F4 & 35.7 & 181 & 0.88 & 1.76 \\
\hline GB-9 & 210 & & F3 & 92.2 & 20.3 & 0.42 & 2.05 \\
\hline GB-8 & 215 & & F3 & 90.8 & 11.6 & 0.75 & 1.56 \\
\hline GB-7 & 220 & & F2 & 69.1 & 11.2 & 0.57 & 1.29 \\
\hline GB-1 & 300 & & F1 & 17.3 & 4.06 & 0.18 & 0.83 \\
\hline \multirow{2}{*}{ SAMPLE } & \multirow{2}{*}{ DEPTH $(\mathrm{cm})$} & \multirow{2}{*}{ FACIES } & ELEMENT ( $\mu \mathrm{g} / \mathrm{kg})$ & T1 & $\mathbf{U}$ & $\mathbf{V}$ & Zn \\
\hline & & & Analytical Error $(\mu \mathrm{g} / \mathrm{kg})$ & 0.05 & 0.1 & 0.2 & 0.3 \\
\hline GB-12 & 170 & & F4 & 0.2 & 0.58 & 24 & 34.1 \\
\hline GB-9 & 210 & & F3 & 0.16 & $\underline{0.42}$ & 30.3 & 21.1 \\
\hline GB-8 & 215 & & F3 & 0.45 & 1 & 31.5 & 17 \\
\hline GB-7 & 220 & & F2 & 0.55 & 1.16 & 18.2 & 11.5 \\
\hline GB-1 & 300 & & F1 & $\underline{0.06}$ & 0.58 & $\underline{15}$ & 8.6 \\
\hline
\end{tabular}

\subsection{Chronology: Radiocarbon Dates (Kiloyears-kyr-) and History}

The lower $85 \mathrm{~cm}$ of core GB (F1 and F2) were deposited between $\sim 4.1 \mathrm{cal} \mathrm{kyr} \mathrm{Be-}$ fore Present -BP- (4290-3980 cal yr BP) and 2.8 cal kyr BP (Table 3). Consequently, a sedimentation rate of $\sim 0.65 \mathrm{~mm} \mathrm{yr}^{-1}$ could be estimated for these facies, because around $85 \mathrm{~cm}$ of sediments were deposited during a 1300-year period. In addition, the projectile fragment corresponds with a 6-pound hand grenade which was used during the Great Siege (1779-1781), a hostile engagement between Great Britain and Spain.

Table 3. Calibrated AMS dates of dated samples.

\begin{tabular}{|c|c|c|c|c|c|}
\hline Core Depth (cm) & Laboratory Code & Sample & ${ }^{14} \mathrm{C}$ age yr BP & $\partial^{13} \mathrm{C}^{0} / 00$ & Calibrated yr BP $(2 \sigma)$ \\
\hline 215 & Beta-290903 & peat & $2680 \pm 30$ & -28.0 & $2750-2850$ \\
\hline 300 & Beta-290904 & peat & $3770 \pm 40$ & -27.9 & $3980-4290$ \\
\hline
\end{tabular}




\section{Discussion}

\subsection{Facies and Paleoenvironments}

F1 and F2 were deposited in a quiet paleoenvironment with abundant underwater vegetation and/or important external inputs of seaweed that gave rise to the peats observed in the lower part of core GB (Figure 1). These features; the low sedimentation rates calculated and the presence of Hydrobia acuta, a brackish gastropod widely distributed in recent Atlantic and Mediterranean lagoons and estuaries [32,33], point to the existence of a shallow lagoon (e.g., The Inundation). Historical sources indicate the presence of large amounts of seaweed in this lagoon, which would cause the deposit of the peat levels observed in this core (F2) [34].

F3 was interpreted as a tsunamiite due to the following features:

(i) Erosional base and rip-up clasts. These two features attest to the erosion of the lagoonal sediments and the transport to the innermost areas of the old Inundation lagoon. They are typical characteristics of tsunamigenic deposits [35] and, more precisely, lagoon paleoenvironments [36,37];

(ii) Basal inverse grading, which is usual in tsunamiites [38,39] and attributed to kinetic sieving by tsunami-induce symmetric waves $[40,41]$;

(iii) Paleontological record. The presence of marine gastropods, such the intertidal and infralittoral species Calliostoma laugieri [42] or groove top shells (J. striatus), common gastropod grazers of Posidonia oceanica leaves [43], as well as a mixing of mollusk assemblages, with species indicative of a range of different source paleoenvironments (brackish Peringia ulvae and marine). The appearance of the two first species would have involved their transport from the marine environments adjacent to The Inundation lagoon by the flushing of the tsunami waves, a common feature in tsunamiites deposited in old coastal lagoons [44,45]. Consequently, this record is very important in determining tsunamiites;

(iv) This abundance of molluscs is associated with an increase in calcite and aragonite, the main components of their shells, as in other tsunamiites [46];

(v) A higher abundance of micas in relation to the underlying deposits, also observed in some tsunamiites [16] due to their suspension, enabling easy transport through the water by the tsunami waves [47];

(vi) Ba increases near the base of F3. Peaks of this element are common in tsunamiites, probably due to the presence of Ba associated with carbonates (e.g., mollusc shells) [48];

(vii) An increase in ferromagnesian elements ( $\mathrm{Ni}, \mathrm{Cr}$, and $\mathrm{V})$, which tend to be more abundant in tsunami sediments than in pre-tsunami sediments [49].

F4 is interpreted as a transition from the previous lagoon to the emerged areas, as can be seen from the substitution of brackish gastropods (e.g., Hydrobia acuta) by terrestrial species (X. apicina, E. fulvus and T. pisana). These last three species are found together in coastal areas, dune systems or anthropized zones, among other places [50]. This facies presents the highest concentrations of some heavy metals (Table 3: group 4), as a probable consequence of spills or other anthropogenic activities (e.g., [51,52]).

\subsection{Dating and History}

The historical data obtained from the projectile fragment indicate that F3 was deposited immediately prior to 1779 . The origin of this tsunamigenic facies would have been the transport of bioclastic marine sands into the interior of The Inundation lagoon during the 1755 Lisbon tsunami. According to the radiocarbon age obtained near the top of F2, this tsunami caused a strong erosion of F2 and the deposit of F3 ( $35 \mathrm{~cm}$ thickness). The thickness of this tsunamiite is very similar to those observed in other deposits attributed to the 1755 Lisbon tsunami in the southwestern Iberian Peninsula $(20-40 \mathrm{~cm})$ [15].

During the 19th century, The Inundation evolved into a swampy and marshy area. Historical data mention large quantities of seaweed and the need for dredging and widening [53], which improved fishing in the area around 1840 [54]. F4 was deposited during this 
paleoenvironmental scenario, which concluded with its definitive anthropogenic filling during the Second World War (F5).

\subsection{The First Mineralogical and Geochemical Evidence of the 1755 Lisbon Tsunami in Gibraltar}

The geological record of the Lisbon tsunami is abundant and varied in the southwestern Atlantic coast of the Iberian Peninsula and North Africa (see Introduction and Figure 1). Nevertheless, this tsunami decreased rapidly east of the Gibraltar Strait, although it still strongly affected some coastal towns. In Ceuta, a Spanish town in North Africa (Figure 1), the mean run-up height was $2 \mathrm{~m}$ [20]. However, the steep slope of this town makes only a small area of its territory susceptible to damage by tsunamis, and no evidence of this tsunami has yet been found [55]. Along the Mediterranean coast of Morocco, the historical tsunami catalogues do not include any references to damage caused by the 1755 Lisbon tsunami [56]. This tsunami did not affect the Rock of Vélez de la Gomera and the town of Melilla (Figure 1), another two Spanish cities located in North Africa about $160 \mathrm{~km}$ and $250 \mathrm{~km}$ east of Gibraltar, respectively [17]. In addition, this high-energy event is not included in the list of tsunami events reported for northern Algeria from the NOAA-NGDC database (http:/ / www.ngdc.noaa.gov/, accessed on 3 September 2021). Consequently, this paper includes the easternmost mineralogical and geochemical evidence of the 1755 Lisbon tsunami near the Atlantic-Mediterranean transition.

\section{Conclusions}

We investigated the sedimentary facies of a core collected in The Inundation, an old lagoon located northern Gibraltar (southern Iberian Peninsula). The sedimentological, paleontological, mineralogical, and geochemical features of selected samples gave new insights into their identification and paleoenvironmental conditions. This core included the transition from a restricted lagoon to terrestrial conditions during the last $\sim 4 \mathrm{cal} \mathrm{kyr}$, passing through a swampy/marsh phase. This transition was interrupted by a bioclastic sandy layer deposited by the 1755 Lisbon tsunami. The waves of this tsunami invaded the internal areas of this ancient lagoon, eroded its bottom, and deposited a tsunamiite with distinctive geological features (erosional base, rip-up clasts, high Ba contents, and important percentages of ferromagnesian elements). This tsunamiite is the first mineralogical and geochemical evidence of this high-energy event in Gibraltar, although its waves also affected other coastal towns near the Strait of Gibraltar according to historical documents. In addition, the macropaleontological record is shown as a powerful tool to differentiate this tsunamigenic layer.

Author Contributions: Conceptualization and methodology: all authors; software: F.R., J.M.M.-P.; validation: J.R.V., M.L.G.-R., J.M.M.-P.; formal analysis: all authors; investigation: all authors; resources: F.R., M.P., J.R.V.; data curation: all authors; writing — original draft preparation: F.R., M.P., J.R.V.; writing—review and editing: M.A. (Manuel Abad), M.I.P., M.I.D., R.M.; visualization: all authors; supervision: F.R., J.R.V.; project administration: F.R.; funding acquisition: F.R., M.P., J.R.V. All authors have read and agreed to the published version of the manuscript.

Funding: This work was carried out through the following projects: a) DGYCIT project CTM200606722/MAR; b) DGYCIT project CGL2006-01412; and c) FEDER 2014-2020 project UHU-1260298. Other funds have come from Autonomous University of Madrid (GPG-418 Research Group) and the Andalusian Government (groups RNM-238, RNM-293 and RNM-349). It is a contribution to the Research Center in Historical, Cultural and Natural Heritage (CIPHCN) of the University of Huelva.

Data Availability Statement: Repositorio Arias Montano, Universidad de Huelva.

Conflicts of Interest: The authors declare no conflict of interest.

\section{References}

1. Prizonwala, S.P.; Gandhi, D.; Bhatt, N.; Winkler, W.; Ravi, M.; Makwana, N.; Bhatt, N. Geological evidence for AD 1008 tsunami along the Kachchh coast, Western India: Implications for hazard along the Makran Subduction Zone. Sci. Rep. 2018, 8, 16816. [CrossRef] [PubMed] 
2. Malik, J.N.; Johnson, F.C.; Khan, A.; Sahoo, S.; Irshad, R.; Paul, D.; Arora, S.; Baghel, P.K.; Chopra, S. Tsunami records of the last 8000 years in the Andaman Island, India, from mega and large earthquakes: Insights on recurrence interval. Sci. Rep. 2019, 9, 18463. [CrossRef] [PubMed]

3. Bahlburg, H.; Spiske, M. The February 27, 2010 Chile Tsunami-Sedimentology of run-up and backflow deposits at Isla Mocha. AGU Abstr. 2010, 2010, OS42B-06.

4. Nentwig, V.; Bahlburg, H.; Gorecka, E.; Huber, B.; Bellanova, P.; Witkowski, A.; Encinas, A. Multiproxy analysis of tsunami deposits-The Tirúa example, central Chile. Geosphere 2018, 14, 1067-1086. [CrossRef]

5. Ishimura, D.; Miyauchi, T. Historical and paleo-tsunami deposits during the last 4000 years and their correlation with historical tsunami events in Koyadori on the Sanriku Coast, northeastern Japan. Progr. Earth Planet. Sci. 2015, 2, 16. [CrossRef]

6. Matsumoto, D.; Sawai, Y.; Tanigawa, K.; Fujiwara, O.; Nemegaya, Y.; Shishikura, M.; Kagohara, K.; Kimura, H. Tsunami deposit associated with the 2011 Tohoku-oki tsunami in the Hasunuma site of the Kujukiri coastal plain, Japan. Island ARC 2016, 25, 369-385. [CrossRef]

7. Scheffers, A.; Kelletat, D. Sedimentologic and geomorphologic tsunami imprints worldwide-A review. Earth Sci. Rev. 2003, 63, 83-92. [CrossRef]

8. Pilarczyk, J.E.; Horton, B.P.; Witter, R.C.; Vane, C.H.; Chagué-Goff, C.; Goff, J. Sedimentary and foraminiferal evidence of the 2011 Tohoku-oki tsunami on the Sendai coastal plain, Japan. Sed. Geol. 2012, 282, 78-89. [CrossRef]

9. Ruiz, F.; Abad, M.; Cáceres, L.M.; Rodríguez Vidal, J.; Carretero, M.I.; Pozo, M.; González-Regalado, M.L. Ostracodes as tsunami tracers in Holocene sequences. Quat. Int. 2010, 73, 130-135.

10. Dura, T.; Hemphill-Haley, E.; Saway, Y.; Horton, B.P. The application of diatoms to reconstruct the history of subduction zone earthquakes and tsunamis. Earth Sci. Rev. 2016, 152, 181-197. [CrossRef]

11. Chagué-Goff, C.; Szczucinski, W.; Shinozaki, T. Applications of geochemistry in tsunami research: A review. Earth Sci. Rev. 2017, 165, 203-244. [CrossRef]

12. Avsar, U. Sedimentary geochemical evidence of historical tsunamis in the Eastern Mediterranean from Ölüdeniz Lagoon, SW Turkey. J. Paleolimnol. 2019, 61, 373-385. [CrossRef]

13. Rodríguez Vidal, J.; Ruiz, F.; Cáceres, L.M.; Abad, M.; González-Regalado, M.L.; Pozo, M.; Carretero, M.I.; Monge, A.M.; Gómez, F. Geomarkers of the 218-209 BC Atlantic tsunami in the Roman Lacus ligustinus: A palaeogeographical approach. Quat. Int. 2011, 242, 201-212. [CrossRef]

14. Donadio, C.; Paliaga, G.; Radke, J.D. Tsunamis and rapid coastal remodeling: Linking energy and fractal dimension. Progr. Phys. Geog. Earth Environ. 2019, 44, 550-571. [CrossRef]

15. Font, E.; Veiga-Pires, C.; Pozo, M.; Nave, S.; Costa, S.; Ruiz, F.; Abad, M.; Simoes, N.; Duarte, S.; Rodríguez Vidal, J. Benchmarks and sediment source(s) of the 1755 tsunami deposit at Boca do Rio Estuary. Mar. Geol. 2013, 343, 1-14. [CrossRef]

16. Kümmerar, V.; Drago, T.; Veiga-Pires, C.; Silva, P.F.; Magalhaes, V.; Mena, A.; Lopes, A.; Rodrigues, A.I.; Schmidt, S.; Terrinha, P.; et al. Exploring Offshore Sediment Evidence of the 1755 CE Tsunami (Faro, Portugal): Implications for the Study of Outer Shelf Tsunami Deposits. Minerals 2020, 10, 731. [CrossRef]

17. Pozo, M.; Ruiz, F.; González-Regalado, M.L.; Carretero, M.I.; Monge, G.; Rodríguez Vidal, J.; Cáceres, L.M.; Abad, M.; Tosquella, J.; Izquierdo, T.; et al. The Origin and Evolution of Late Holocene Tsunamiites in the Doñana National Park (SW Spain): Trace Elements and Geochemical Proxies. Minerals 2020, 10, 756. [CrossRef]

18. Solares, J.M.M.; Arroyo, A.L. The great historical 1755 earthquake. Effects and damage in Spain. J. Seismol. 2004, 8, 275-294. [CrossRef]

19. Silva, P.G.; Gómez-Diego, P.V.; Elez, J.; Giner-Robles, J.L.; Rodríguez-Pascua, M.A.; Roquero, E.; Martínez-Graña, A.; Bardají, T.; Bautista, B. Eartquake environmental effects of the AD 1755 Lisbon tsunami in Spain. In Resúmenes IX Reunión del Cuaternario Ibérico, Faro; AEQUA: Roma, Italy, 2017; pp. 53-57.

20. Solares, J.M.M. Los Efectos En España Del Terremoto De Lisboa (1 De Noviembre De 1755); Ministerio de Fomento: Madrid, Spain, 2001.

21. Baptista, M.A.; Miranda, J.M. Revision of the Portuguese catalog of tsunamis. Nat. Hazards Earth Syst. Sci. 2009, 9, 25-42. [CrossRef]

22. Omira, R.; Baptista, M.A.; Mellas, S.; Leone, F.; Meschinet de Richemond, N.; Zourarah, B.; Cherel, J.-P. The November 1st, 1755 Tsunami in Morocco: Can Numerical Modeling Clarify the Uncertainties of Historical Reports? In Tsunami-Analysis of a Hazards - From Physical Interpretation to Human Impact; López, G., Ed.; IntechOpen: London, UK, 2012; pp. 61-76.

23. Baptista, M.A.; Heitor, S.; Miranda, J.M.; Miranda, M.A.; Victor, L.M. The 1755 Lisbon tsunami: Evaluation of the tsunami parameters. J. Geodyn. 1998, 25, 143-157. [CrossRef]

24. Roger, J.; Baptista, M.A.; Sahal, A.; Accary, F.; Allgeyer, S.; Hebert, H. The Transoceanic 1755 Lisbon Tsunami in Martinique. Pure Appl. Geophys. 2010, 168, 1015-1031. [CrossRef]

25. Dabrio, C.J.; Goy, J.L.; Zazo, C. The record of the tsunami produced by the 1755 Lisbon earthquake in Valdelagrana spit (Gulf of Cádiz, southern Spain). Geogaceta 1998, 23, 31-34.

26. Whelan, F.; Kelletat, D. Boulder Deposits on the Southern Spanish Atlantic Coast: Possible Evidence for the 1755 AD Lisbon Tsunami? Sci. Tsun. Hazards 2005, 23, 25-38.

27. Cuven, S.; Paris, R.; Falvard, S.; Miot-Noirault, E.; Benbakkar, M.; Schneider, J.-L.; Billy, I. High-resolution analysis of a tsunami deposit: Case-study from the 1755 Lisbon tsunami in southwestern Spain. Mar. Geol. 2013, 337, 98-111. [CrossRef] 
28. Schultz, L.G. Quantitative Interpretation of Mineral Composition from X-ray and Chemical Data for the Pierre Shale. 1964. Available online: https:/ / pubs.er.usgs.gov/publication/pp391C (accessed on 3 September 2021).

29. Vidihna, J.M.; Rocha, F.; Andrade, C.; Gomez, C.; Freitas, C. Clay Minerals-A Mineralogical Tool to Distinguish Beach from Dune Sediments. J. Coast. Res. 2007, S150, 216-220.

30. Sivasamandy, R.; Ramesh, R. Clay Mineralogy of Surface Sediments of Kolakkudi Lake, Musiri Taluk, Tiruchirapalli District. Tamil Nadu, India. Int. J. Res. 2015, 2, 646-657.

31. Reimer, P.J.; Baillie, M.G.L.; Bard, E.; Bayliss, A.; Beck, J.W.; Blackwell, P.G.; Bronk Ramsey, C.; Buck, C.E.; Burr, G.S.; Edwards, R.L.; et al. IntCal09 and Marine09 radiocarbon age calibration curves, 0-50,000 years cal BP. Radiocarbon 2009, 51, 1111-1150. [CrossRef]

32. Wilke, T.; Rolán, E.; Davis, G.M. The mudsnail genus Hydrobia s.s. in the northern Atlantic and western Mediterranean: A phylogenetic hypothesis. Mar. Biol. 2000, 137, 827-833. [CrossRef]

33. Ware, F. Scottish Invertebrate Discoveries: The hardy invertebrates thriving in Scotland's saline lagoons. Scott. Invertebr. News 2014, 5, 5-6.

34. Kelaart, E.F. Flora Calpensis. Contributions to the Botany and Topography of Gibraltar and Its Neighbourhoud: With Plan, and Views of the Rock; John Van Voorst: London, UK, 1846.

35. Dawson, A.G.; Shi, S. Tsunami deposits. Pur. Appl. Geophys. 2000, 157, 875-897. [CrossRef]

36. Garrison-Laney, C.E. Diatom Evidence for Tsunami Inundation from Lagoon Creek, a Coastal Freshwater Pond, Del Norte County, Carolina. Ph.D. Thesis, Humboldt State University, Arcata, CA, USA, 1998.

37. Kempf, P.; Moernaaut, J.; Van Daele, M.; Vandoorne, W.; Pino, M.; Urrutia, R.; De Batist, M. Coastal lake sediments reveal 5500 years of tsunami history in south central Chile. Quat. Sci. Rev. 2017, 161, 99-116. [CrossRef]

38. Goff, J.; Nichol, S.; Kennedy, D. Development of a tsunami database for New Zealand. Nat. Hazards 2010, 54, 193-208. [CrossRef]

39. Naruse, H.; Arai, K.; Matsumoto, D.; Takahashi, H.; Yamashita, S.; Tanaka, G.; Murayama, M. Sedimentary features observed in the tsunami deposits at Rikuzentakata City. Sed. Geol. 2012, 282, 199-215. [CrossRef]

40. Shanmugam, G. Process-sedimentological challenges in distinguishing paleo-tsunami deposits. Nat. Hazards 2012, 63, 5-30. [CrossRef]

41. Higman, B.; Jaffe, B.E. A comparison of grading in deposits from five tsunamis: Does tsunami wave duration affect grading patterns? EOS Trans. Am. Geophys. Union 2005, 86, T11A-0362.

42. Huc, S. The first documented finds of Calliostoma laugieri (Payraudeau, 1826) (Gastropoda: Calliostomatidae) on the coastal mollusc shell deposit at Ankaran. Nat. Slov. 2019, 21, 55-56.

43. Donnarumma, L.; Bruno, R.; Terlizzi, A.; Russo, G.F. Population ecology of Jujubinus striatus and Jujubinus exasperatus (Gastropoda: Trochidae) in a Posidonia oceanica seagrass bed. Eur. Zool. J. 2018, 85, 17-25. [CrossRef]

44. Ruiz, F.; Rodríguez Ramírez, A.; Cáceres, L.M.; Rodríguez Vidal, J.; Carretero, M.I.; Abad, M.; Olías, M.; Pozo, M. Evidence of high-energy events in the geological record: Mid-Holocene evolution of the southwestern Doñana National Park (SW Spain). Palaeogeog. Palaeoclimat. Palaeoecol. 2005, 229, 212-229. [CrossRef]

45. Donato, S.V.; Reinhart, E.; Boyce, J.I.; Rothaus, R.; Vosmer, T. Identifying tsunami deposits using bivalve shell taphonomy. Geology 2008, 36, 199-202. [CrossRef]

46. Smit, J.; Laffra, C.; Meulenaars, K.; Montanari, A. Probable late Messinian tsunamiites near Monte Dei Corvi, Italy, and the Nijar Basin, Spain: Expected architecture of offshore tsunami deposits. Nat. Hazards 2012, 63, 241-266. [CrossRef]

47. Jagodzinski, R.; Sternal, B.; Szczucinski, W.; Lorend, S. Heavy Minerals in 2004 Tsunami Deposits on Kho Khao Island, Thailand. Polish. J. Environ. Stud. 2009, 18, 103-110.

48. Ramírez-Herrera, M.T.; Lagos, M.; Hutchinson, I.; Kostoglodov, V.; Machain, M.L.; Caballero, M.; Goguitchaichvili, A.; Aguilar, B.; Chagué-Goff, C.; Goff, J.; et al. Extreme wave deposits on the Pacific coast of Mexico: Tsunamis or storms?-A multi-proxy approach. Geomorphology 2012, 139-140, 360-371. [CrossRef]

49. Jayawardana, D.T.; Ishiga, H.; Pitawala, H.M.T.G.A. Geochemistry of surface sediments in tsunami-affected Sri Lankan lagoons regarding environmental implications. Int. J. Environ. Sci. Technol. 2012, 9, 41-55. [CrossRef]

50. Ruiz, A.; Cárcaba, A.; Porras, A.; Arrébola, J.R. Caracoles Terrestres De Andalucía. Guía Y Manual De Identificación; Junta de Andalucía: Seville, Spain, 2006; p. 304.

51. Zubala, T.; Patro, M.; Boguta, P. Variability of zinc, copper and lead contents in sludge of the municipal storwater treatment plant. Environ. Sci. Pollut. Res. Int. 2017, 24, 17145-17152. [CrossRef]

52. Emmons, A.M.; Bizimis, M.; Lang, S.Q.; Stangler, W.; Geidel, G.; Baalousha, M.; Wanamaker, E.; Rothenberg, S.E. Enrichments of metals, including methylmercury, in sewage spills in south Carolina, USA. J. Environ. Qual. 2018, 47, 1258-1266. [CrossRef] [PubMed]

53. Grenville, R.T.N.B.C. The Private Diary of Richard, Duke of Buckingham and Chandos; Hurst \& Blackett: London, UK, 1856; Volume 1, p. 341.

54. Lt. Col. Wilkie. The British Colonies considered as Military Posts. United Serv. Mag. 1840, $33,381$.

55. Abad, M.; López González, N.M.; Delgado, J.; Rodríguez-Vidal, J.; Chamorro, S.; Cáceres, L.M. Análisis y cartografía de peligrosidad geológica en el litoral de Ceuta. Rev. Soc. Geol. España 2010, 23, 35-53.

56. Kaabouben, F.; Baptista, M.A.; Iben Brahim, A.; El Mouraouah, A.; Toto, A. On the Moroccan tsunami catalogue. Nat. Hazards Earth Syst. Sci. 2009, 9, 1227-1236. [CrossRef] 